Studies in African Linguistics

Volume 31, Numbers 1/2, 2002

\title{
DERIVATIONAL PROCESSES IN RANGI
}

\author{
Oliver Stegen \\ SIL
}

The main object of research described in this paper is Rangi, a scarcely investigated Bantu language of Northern Central Tanzania. Rangi phonology and morphonology are briefly sketched, including a classification with regard to both Vowel Height Harmony and Advanced Tongue Root activity. The main body of the paper consists of a detailed description of Rangi derivational processes, which follows the pattern established in Maganga and Schadeberg's description of Nyamwezi, a closely related language. Both verbal derivation, which exclusively uses the extensional slot of the verb structure, and nominal derivation, which employs noun class prefixes and a few suffixes, are covered.

\section{Introduction}

It is no secret that despite decades of thorough linguistic work on Bantu languages, there are still a great many descriptive gaps. The aim of this paper is to address one such gap explicitly mentioned in the literature: "little public information is available on Langi" [Nurse 1999:11]. Rangi ${ }^{1}$ is a North-Eastern Bantu language, classified as F.33 [Guthrie 1967-71II:48], spoken by 310,000 people [Grimes 2000] in the Kondoa District of Northern Central Tanzania. The data on which the observations reported herein are based was collected during the

1 While the self-referent of the language is KIla:ngi, it is usually called Rangi in both English and Swahili. As this paper is written in English, the language will be refered to as Rangi throughout. 
author's stay in Rangi-speaking country. ${ }^{2}$ Of course, any language description has to be selective, and this one is no exception. The main focus of the paper is the description of verbal and nominal derivation. However, by way of introduction, many phonological and morphonological aspects which could be of particular interest are supplied as well, mainly in subsections 1.1 through 1.3.

Of previous linguistic research on Rangi, only Seidel [1898], Dempwolff [1916] and Akhavan [1990] go beyond phonological aspects and include at least some derivational processes, yet most of this treatment is sketchy and rather general. ${ }^{3}$ Considering that Akhavan [1990] uses previously unpublished data collected by Berger in 1935, hardly any morphological data on Rangi younger than sixty years seems to be readily available. ${ }^{4}$

For an outline, Maganga \& Schadeberg's [1992] description of Nyamwezi (henceforth M\&S92) has been followed as an example, as it is probably the best and most comprehensive publication on another Bantu $\mathrm{F}$ language, hence quite relevant to studies in Rangi. It contains a rather detailed section on derivation (M\&S92:147-190) which has been very helpful for the organization of this paper. In addition, Schadeberg [2002] was consulted, and phenomena not mentioned in M\&S92 were added.

1.1. Phonological considerations. In this subsection, the segmental and suprasegmental inventory of Rangi will be summarized, specifically consonants, vowels, and tones. Table 1 shows the consonant phonemes of Rangi. All conso-

2 My stays at Kondoa town from June 1997 to August 1998 and at Mnenya village from September 1998 to June 2000 were made possible by a residence permit, nr. C 42314, at the invitation of the Anglican Diocese of Central Tanganyika to whom I am most grateful. I am indebted to those Rangi who provided information about their mother tongue, foremost among them Rajabu Isangu and Saada Saidi (of Kolo-Mnenya), Mama Bahati (of Kondoa-Ausia), Samweli Ramadhani (of Haubi-Kalamba), and Andrew Lujuo (of Mondo-Soya). Distinctions between the four dialects (Haubi, Kondoa, Kolo, and Mondo) are mainly phonetic and lexical, and hence do not play a significant role in the consideration of derivation. Further, I want to thank Ron Moe (for help with managing the data with the Shoebox software), staff and participants of the SIL AFA morpho-syntax workshop September 2001 at the BTL Ruiru Centre (for providing the perfect environment for writing the first versions of this paper), Rod Casali, Derek Nurse, Thilo Schadeberg, Karen VanOtterloo, and Joost Zwarts, as well as an anonymous reviewer and the editor of SAL (for insightful comments), and my wife Dorothea (for supporting me in every way possible). The usual disclaimers apply, of course.

3 Dempwolff [1916:121-122] contains a list of functional suffixes following verbal stems, yet does not subsume allomorphs under one morpheme, e.g., -Ir- and -er- under applicative (cf. sections 1.3 and 2.2.3).

4 Dunham [2001] was not received in time for consideration in this paper. 
nants except $w$ have been found with labialized, and all consonants except $p, d z$, $n d z$ and $n$ with palatalized modification. Absence of $p y$ results from Proto-Bantu *pi having become Rangi fy, e.g., *-píát-corresponds to -fyáata 'to seize'.

Table 1: Consonant phoneme chart

\begin{tabular}{|c|c|c|c|c|c|c|c|c|c|}
\hline \multirow[b]{2}{*}{ voicing } & \multicolumn{2}{|c|}{ labial } & \multicolumn{2}{|c|}{$\begin{array}{l}\text { dental- } \\
\text { alveolar }\end{array}$} & \multicolumn{2}{|c|}{ palatal } & \multicolumn{2}{|c|}{ velar } & glottal \\
\hline & - & + & - & + & - & + & - & + & - \\
\hline $\begin{array}{c}\text { plosives } \\
\text { oral } \\
\text { prenas. }\end{array}$ & $\begin{array}{c}\mathrm{p} \\
\mathrm{mp}\end{array}$ & $\begin{array}{c}\mathrm{b} \\
\mathrm{mb}\end{array}$ & $\begin{array}{c}\mathrm{t} \\
\mathrm{nt}\end{array}$ & $\begin{array}{c}\mathrm{d} \\
\text { nd }\end{array}$ & $\begin{array}{l}\text { t6 } \\
\text { ntc }\end{array}$ & $\begin{array}{c}\mathrm{dz} \\
\mathrm{ndz}\end{array}$ & $\begin{array}{c}\mathrm{k} \\
\mathrm{jk}\end{array}$ & $\begin{array}{c}\mathrm{g} \\
\mathrm{gg}\end{array}$ & \\
\hline fricatives & $\mathrm{f}$ & $\mathrm{v}$ & $\mathrm{S}$ & & & & & & $\mathrm{h}$ \\
\hline nasals & & $\mathrm{m}$ & & $\mathrm{n}$ & & $\mathrm{n}$ & & $\eta$ & \\
\hline liquids & & w & & $1, \mathrm{r}$ & & $\mathrm{y}$ & & & \\
\hline
\end{tabular}

An unusual feature is the palatalized palatal approximant yy. Phonetically, the difference is that between non-syllabic [I] and non-syllabic [i]. Contrasting words are given in (1). Note that palatalized $s$ is realized as $[6]$ which, consequently, has not been analyzed as a phoneme in its own right.
(1)
a. Lusaya
'cheek' versus
kuváyya
'to trip s.o.'
b. kuséya
'to say'
versus
kuséyya
'to remove'

Care also has to be taken to distinguish the palatalized alveolar nasal ny, realized with apical contact, from the palatal nasal $n$, which is realized dorsally. Admittedly, the near-minimal pair shown in (2) exhibits major differences in morphological build-up as well as additional distinctiveness in tone and stress.
(2)
a. kulứmána
$<\quad$ ku+lú+mán+a
'to know it (cl.11)'
b. ku'lúmanya
$<\quad$ ku+lúman+i+a
'to cause to meet'

The vowel phonemes are charted in Table 2 . Note that vowel length is distinctive, as shown in (3), but instances of long vowels after labialized or palatalized consonants and before prenasalized plosives are attributable to compensatory lengthening (cf. section 1.3). In order to facilitate the marking of tone, long vowels will be written with double letters rather than with following ' $:$.
(3)
a. kuláva 'to sprain'
versus
kuláava
'to wake up early'
b. mukúlu 'father-in-law'
versus
mukưúlu
'elder brother' 
Table 2: Vowel phoneme chart

\begin{tabular}{|l|c|c|c|c|}
\cline { 2 - 5 } \multicolumn{1}{c|}{} & \multicolumn{2}{c|}{ front } & \multicolumn{2}{c|}{ back } \\
& short & long & short & long \\
\hline extra-high (+ATR) & $\mathrm{i}$ & $\mathrm{i}:$ & $\mathrm{u}$ & $\mathrm{u}:$ \\
\hline high (-ATR) & $\mathrm{I}$ & $\mathrm{I}:$ & $\mathrm{v}$ & $\mathrm{U}:$ \\
\hline mid (-ATR) & $\varepsilon$ & $\varepsilon:$ & $\mathrm{o}$ & $\mathrm{o}:$ \\
\hline low & \multicolumn{4}{c|}{$\mathrm{a}$} \\
\hline
\end{tabular}

Table 3: Tones on short and long vowels short vowel

low tone

mbava

'cockroach'

mukuve

'navel'

long vowel

low tone

baanka

'room'

kIkuongu

'epidemic' high tone

ibáta

'duck'

mukúlv

'father-in-law' high tone

mpááha

'fingernail'

mukúúlu

'elder brother' rising tone

ibaándI

'grasshopper'

ikuúngulv

'pied crow' falling tone

ibáanda

'hut'

kIkúungu

'cockspur'

In Rangi, there are high and low tones (marked with acute accent and unmarked, respectively). As shown in Table 3, short vowels occur with high or low tone whereas long vowels occur with high, low, rising or falling tone. This is an indication of the fact that the mora, and not the syllable, is the tone bearing unit in Rangi.

A phrase-final $\mathrm{H}$ tone deletion rule operates in Rangi. All words ending in $\mathrm{H}$ tone underlyingly, regardless of how many syllables this $\mathrm{H}$ tone spans, are realized as low at the end of an utterance, including in isolation, only retaining their $\mathrm{H}$ tones phrase-initially or -medially. Examples of this effect are shown in (4), contrasting nouns in isolation and with following demonstrative pronoun. Example (4a), taking a low tone item from table 3, shows that there are true underlyingly $\mathrm{L}$ tone nouns which do not exhibit a $\mathrm{H}$ tone if followed by a 
demonstrative. This low tone realization of lexical items in isolation, as in (4a-e), could account for the fact that, in the literature, Rangi is often portrayed as having lost at least part of its tonal distinctiveness [e.g., Guthrie 1967-71II:48, Nurse 1999:23]. Examples (4d-e) show that a single $\mathrm{H}$ tone can be assigned to more than one mora. Also, two separate $\mathrm{H}$ tones can be assigned to a nominal stem underlyingly, as shown in examples (4f-i). Of these, (4h-i) seem to constitute a violation of the Obligatory Contour Principle. Of course, the lexical stems concerned could have been bimorphematic in the past. However, there remains no synchronic evidence of this.
a. mukuvu
versus
mukuve uhu
'(this) navel'
b. mudala
versus
mudalá uhu
'(this) old woman'
c. nororosda
versus
nororoodá IhI
'(this) kind of snake'
d. mulume
versus
mulúmé uhu
'(this) husband'
e. mbavariri versus
mbávárírí IhI
'(this) sorrow'
f. kitçámpihi
kitcámpihí IkI
'(this) rafter'
g. ibaáhıra
versus
ibaáhIrá IrI
'(this) feather'
h. nkóngoodzo
versus
jkóngóódzó IhI
i. nté́tere
versus
versus ntećtéré IhI
'(this) butterfly'
'(this) pumpkin seed'

On verbs, lexical tone distinctions seem to have been lost. ${ }^{5}$ Every verbal stem receives one $\mathrm{H}$ tone which, as shown in (5), is assigned to the ante-penultimate stem mora and spreading to any preceding stem morae. On stems shorter than three morae, as in (5a-b), the earliest possible stem mora receives the $\mathrm{H}$ tone.

(5)
a. kuryá
b. kusćka
c. kulóola
d. kukéngécdza
e. kudáláhala
f. kuryáánírírrya

Rangi makes use of grammatical tone. As shown in (6), the tone on the imperative is displaced to the right edge compared to the tone on the infinitive.

5 In the minor dialect of Kolo, tonal minimal pairs have been recorded for verbs lexically. These are disregarded here, however, as both the two major dialects of Haubi and Kondoa and the other minor dialect of Mondo do not exhibit these. 
(6)
a. kubóka
versus
boká necdza
'dig (well)'
b. kufyááhıra
versus
fyaahírá necdza
'sweep (well)'
c. kuláhírímrya
versus
lahıríryá nędza
'order (well)'

As shown in (7), the verbal tense-aspect forms for distant past and past habitual are distinguished by tone only. A detailed analysis of verbal tone is beyond the scope of this paper. The interested reader is referred to Akhavan [1990].
a. nabókaa 'I used to dig' versus
nábokáa 'I dug (long ago)'
b. atcérévaa 'he used to be late' versus átcereváa 'he was late (long ago)'
c. vasérérékéraa 'they used to slide down' versus vásererckeráa 'they slid down (long ago)'

1.2. Morphological considerations. Only two morphological features are relevant to the derivational processes described herein, viz. the structure of the verb and the class prefixes on noun stems. The basic order of components in a verb is (with optional components in brackets):

\section{Subject - Tense/Aspect - (Object) - Root - (Extension) - Final Vowel}

A few instances of the verb structure are given in (8). In the following sections, underlying tone is shown on nouns, but surface tone on verbs. 6

6 The following abbreviations are used:
APPL applicative
IND indicative
CAUS causative
NEG negative
PRES present
CON consecutive
PASS passive
PST past
CONT continuous
PFV perfective
SUBJ subjunctive
$1 \mathrm{~S}, 3 \mathrm{~S}$ first, third person singular

A number alone refers to a noun class. Other transcription conventions will be mentioned in section 1.3 according to the morphonological process they relate to. 


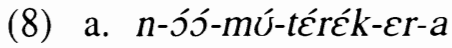

1S-PRES:CONT-3S-cook-APPL-IND

'I am cooking for him.'

b. tc-á-n-tưrínt-y-a

7-PST-1S-be_crazy-CAUS-IND

'It drove me crazy.'

c. áá-n-dah-ír-e

3S:PRES-1S-show-APPL-SUBJ

'He should show me.'

An overview of noun class prefixes is given in table 4 .

Table 4: Noun class prefixes

\begin{tabular}{|l|l|l|l|l|l|l|l|l|l|}
\cline { 2 - 9 } \multicolumn{1}{c|}{} & $1 / 2$ & $3 / 4$ & $5 / 6$ & $7 / 8$ & $9 / 10$ & $11 / 10$ & $12 / 19$ & 14 & 15 \\
\hline sg & $m u-$ & $m u-$ & $i-$ & $k I^{-}$ & $\mathrm{N}-$ & $l u-$ & $k a-$ & $U^{-}$ & $\mathrm{k}-$ \\
\hline $\mathrm{pl}$ & va- & mI- & ma- & $v i-$ & $\mathrm{N}-$ & $\mathrm{N}-$ & $f i-$ & & \\
\hline
\end{tabular}

Note that, as is common in Eastern Bantu languages, prefixes of noun classes 9 and 10 consist of an underlyingly unspecified nasal which assimilates in place of articulation to following plosives, as in (9a-c). It elides before other consonants, as in (9d-f),7 and is realized as [n] when preceding vowel-initial stems, as in $(9 \mathrm{~g})$.

(9) a. mbere 'front'

b. ntshe 'dung'

c. Ikala 'mongoose'

d. fííwa 'kidney'

e. haálı 'joke'

f. sálu 'sand'

g. necre 'badger'

1.3. Morphonological considerations. Several morphonological processes are relevant for the description of derivation in Rangi. Most of the processes described in the following concern vowel harmony or vowel coalescence, and

7 Prenasalized $/ \mathrm{mv} /$ was not found in the corpus. Class 9 nouns with initial $v$ include viryo 'grain' and vúdv 'dikdik'. 
they apply foremost to verbal suffixes and noun class prefixes. In verbal extensions with the vowels $I$ and $v$, asymmetric vowel height harmony occurs after stems with the vowels $\varepsilon$ and 0 . That means that $I$ is lowered to $\varepsilon$ after both $\varepsilon$ and $\supset$ while $v$ is lowered to $\supset$ only after $\supset$, as shown in (10). The verbal extensions concerned are the Applicative -Ir- and the transitive Separative - $v I$ -
(10) a. -hák-Ir-a 'smear at/for'
b. -kér-er-a 'cut at/for'
c. -bók-er-a 'dig at/for'
d. -hál-ul-a 'strip off'
e. -bénd-ol-a 'break off'
f. -hón-गl-a 'wipe off'

Vowel harmony has been analyzed in detail and across a substantial proportion of Bantu languages by Hyman [1999], yet that study does not include data on Rangi. Rangi would accordingly be classifiable as a seven vowel language with canonical Vowel Height Harmony, as all five properties of that harmony apply in Rangi: the above shown asymmetry, the facts that a neither triggers nor undergoes harmony, and that harmony does not apply to either final vowels or prefix vowels [Hyman 1999:238].

Prefixes with the vowels $I$ and $v$ either desyllabify on vowel-initial stems leading to compensatory lengthening of the stem-initial vowel, or they coalesce assimilating completely in the process. Such lengthened vowels are transcribed as long. Table 5 shows these processes for the prefixes of noun classes 3 and 4 , being singular and plural of the respective noun stems.

Table 5: Vowel coalescence of noun class prefixes 3 and 4

\begin{tabular}{|c|c|c|c|}
\hline \multicolumn{2}{|c|}{ mu- (class 3$)$} & \multicolumn{2}{|c|}{$m_{I^{-}}$(class 4$)$} \\
\hline$U+a>$ waa & mwaáká 'year' & I $+\mathrm{a}>$ yaa & myaáká 'years' \\
\hline$U+\varepsilon>w \varepsilon \varepsilon$ & mwع́́rí 'moon' & $\mathrm{I}+\varepsilon>\mathrm{y} \varepsilon \varepsilon$ & myعźrí 'months' \\
\hline$U+I>$ WII & no example found & I+I $>$ II & no example found \\
\hline$v+\mathrm{i}>$ wii & mwiíwa 'thorn' & $\mathrm{I}+\mathrm{i}>\mathrm{ii}$ & miîwa 'thorns' \\
\hline$u+0>00$ & mooda 'medicine' & $\mathrm{I}+0>$ yos & myooda 'medicine' \\
\hline$U+U>v U$ & mứmbu 'calabash' & $\mathrm{I}+\mathrm{U}>\mathrm{y} v \mathrm{U}$ & myứmbu 'calabashs' \\
\hline$u+u>u u$ & muumu 'figtree' & $\mathrm{I}+\mathrm{u}>$ yuu & myuumu 'figtrees' \\
\hline
\end{tabular}


Even though no example with vowel initial $I$ was found, the outcome is still predictable. Remarkably, the front-back asymmetry shows again, in that $I$ desyllabifies preceding both $\varepsilon$ and $\supset$, while $v$ desyllabifies before $\varepsilon$ only but assimilates to 0 .

While most vowels before prenasalized consonants are long, indicating compensatory lengthening, some exceptions as shown in (11) have been found.
(11) a. musinga 'child'
b. Đkứnde 'dove (species)'
c. iyombé 'price, trade'

Complementary lengthening due to prenasalized consonants applies predominantly to the penultimate position which, as in many Bantu languages, normally receives stress in Rangi. Examples of lengthening in other positions are given in (12).
(12) a. mukaandála
'belt'
b. mukứngúdzo 'firefly'
c. kamúúntçưru 'small robe'

Especially in the ante-penultimate position of verbs, vowel length contrasts occur before prenasalized consonants, as shown in (13).
(13)
$\begin{array}{lllll}\text { a. kusć́́ngula 'strip' } & \text { but kusóngola 'carve' } \\ \text { b. kusáámbula 'destroy' } & \text { but } & \text { kusúmpula 'bother' }\end{array}$
c. kutcúúngira 'wrap up' but kusúngira 'peep'
d. kuyééndera 'visit' but kubéndula 'break off'

Another process of vowel harmony is leftward [+ATR] spreading which applies both from stems onto prefixes and from suffixes onto stems. This process has been investigated cross-linguistically by Casali [1998], and Rangi fits in accordingly as a seven [i i $\varepsilon$ a $\supset v$ u ] vowel system with dominant [+ATR]. The vowels [i] and [u] spread their [+ATR] feature leftward, resulting in [+ATR] variants $\left[\begin{array}{lll}\mathrm{i} & \mathrm{o} & \mathrm{u}\end{array}\right]$ of the underlyingly [-ATR] vowels [ $\left[\begin{array}{llll}\mathrm{I} & \varepsilon & 0 & u\end{array}\right]$. This process seems to be gradient, i.e., having diminished effect with increasing distance from the [+ATR] spreading vowel. Underlying rather than harmonized vowels will be written in all instances. In (14), phonetic realizations of two phonemic forms containing leftward [+ATR] shift are shown. 


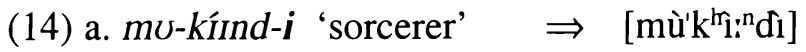

b. mu-lósl-i 'bridegroom' $\Rightarrow$ [mừ'lộ:Ii]

In root-final position of verbs, the liquids $r$ and $l$ are found in complementary distribution, with $r$ before front, and $l$ before back vowels. Consequently, suffixes with front vowels effect a change of $I$ to $r$ in the last consonant position of the stem. In a second step, inter-liquid front vowels can then be optionally deleted as shown in (15).

$$
\begin{array}{ll}
\begin{array}{l}
\text {-tcúúngula }+-I r \\
\text { 'untie' }
\end{array} & \Rightarrow \quad \begin{array}{l}
\text {-tcúúngúrira } \\
\text { 'untie for' }
\end{array}
\end{array}
$$

While other morphonological processes exist, these are not directly relevant for the main body of this paper, i.e., the description of derivation in Rangi.

\section{Verbal Derivation}

Verbal derivation in Rangi is restricted to the extension slot in the verb structure. It can be differentiated into nonverb-to-verb and verb-to-verb derivation.

2.1. Nonverb-to-verb derivation. Only one nonverb-to-verb derivational morpheme has been observed, namely, the suffix -ha8 in the extensional slot of the verb structure. The morpheme is non-productive, and for some verbs given in (16), the original noun or adjective can no longer be established.
a. -néncha
'become fat'
(cf. -néne 'fat')
b. - rútaha
'become heavy'
(cf. -ruto 'heavy')
c. -ángưha
'become light'
(cf. tcangutcáangu 'quickly')
d. -lóngoha
'tell a lie'
(cf. ulóóngś 'lie')
e. -lírha
'be long'
f. -bósha
'be good'
g. - vírha
'be bad'

8 The final -a of this suffix is actually the final vowel slot of the verb structure. In the literature, this nonverb-to-verb derivational suffix is often called 'inchoative'. 
2.2. Extensions. Verb-to-verb derivation is confined to the extensional slot of the verb structure. ${ }^{9}$ In the following, productive extensions will be discussed before non-productive ones.

2.2.1 Passive. Passive is marked by the suffix $-W-.10$ A longer form -iw- has only been found in ríiwa 'to be eaten'. Passive $-W$ - can be affixed to all transitive verbs a few examples of which are shown in (17). The passives in (17d-e) lose their root-final consonant, for which there is no regular explanation. The passive in (17f) does not seem to have a corresponding active form. It should be noted that the combination of passive $-w$-with the perfective suffix -ire results in -irwe.
(17) a. -lóslwa
'be married'
(cf. -lócla 'marry')
b. -lúmwa
'be bitten'
(cf. -lúma 'bite')
c. -vyáalwa 'be born'
(cf. - vyáala 'beget, give birth')
d. -úlawa
'be killed'
(cf. -úlaha 'kill')
e. -hécwa
'be given'
f. -vírwa
'be ripe, ripen'
(cf. -hécra 'give')

One function of passives is to de-emphasize the agent of a transitive phrase. In examples such as those in (18), the agent of the action need not be mentioned at all.

9 In Rangi, as in other Bantu $F$ languages, the reciprocal suffix -an- has merged semantically with the reflexive marker -i- that occupies the object marker slot of the verb structure. Some forms with -an- have survived, although these are now non-productive (cf. section 2.2.6). While the reciprocal/ reflexive prefix -1-is inflectional, several examples are given below in which some seem to have become lexicalized. Whether Rangi employs devices for distinguishing between those two meanings has not been established.
a. -íhála 'scratch oneself' (cf. -hála 'scrape')
b. -ítécra 'feel' (cf. -técra 'hear')
c. -ívísa 'hide oneself' (cf. - vísa 'hide')
d. -ísúka 'plait own hair' (cf. -súka 'plait hair')
e. -íláha 'take an oath' (cf. -láha 'promise')
f. -ídzíinga 'assemble' (cf. -dźiinga 'collect')
g. -ílósla 'marry each other' (cf. -lósla 'marry')
h. -íréka 'leave each other' (cf. -réka 'leave')
i. -íváa 'hit each other, fight' (cf. -váa 'hit')

10 Whether $-w$ - is underlyingly - - - which subsequently desyllabifies cannot be decided from synchronic evidence. 
(18) idzó nưmbá y-a-táás-irwe

yesterday house 9-PRES-plaster-PFV:PASS

'Yesterday, the house was plastered.'

2.2.2. Causative. Causative is marked by the suffix $-y$-. Underlyingly, this $-y-$ must be $-i$-, as it spreads [+ATR] to the left, e.g., (10b) -linhya is phonetically [rìh'à]. The longer form -isy- has been observed in -ríisya 'to feed' from -ryá 'to eat'. Like the passive, causative $-y$-is incorporated into the perfective suffix -ire, resulting in -iirye. Most causatives, as shown in (19), are transparent with regard to their derivation. Others, as in (20a-c), seem to have undergone a semantic shift or, as in (20d-e), are no longer connected to a form used synchronically.
(19) a. - -5fya
'frighten'
(cf. -ófa 'fear')
b. -línhya
'lengthen'
(cf. -líha 'be long')
c. -kíimya
'lower down'
(cf. -kíima 'descend')
d. -mémya
'fill'
(cf. -méma 'be full')
(20) a. -láhya 'show'
b. -kéchya 'reduce'
c. -bósya 'do/think'
d. -úrya 'ask'
e. -néyya 'sleep'
(cf. -láha 'promise')
(cf. -kécha 'breathe')
(possibly related to -bósha 'be good')

At least one non-causative verb borrowed from Swahili, viz. -tosha with [ $]$ ] in root-final position, has been reinterpreted as causative, i.e., -tóoça 'to be sufficient'.11

2.2.3. Applicative. The Applicative is marked with the suffix -Ir-/-Er-. It is a productive morpheme which is heavily used in everyday language, adding a participant to a verb's action or event. The two most common uses which can be applied to most verbs are benefactive and locational, as shown in (21). Note that (21e) is locational only. Other uses include intensive (22a-b), instrumental (22cd), directional (22e-f), and circumstantial or reason $(22 \mathrm{~g})$.

11 This reinterpretation becomes evident in the perfective form yatóśíirye 'it has been enough' where the causative $-y$ - is incorporated into the perfective suffix -ire. Unlike in Swahili, []] does not exist in the Rangi phoneme inventory, the closest sound being [G], which is the realization of palatalized $/ \mathrm{s} /$. 
(21) a. -bókera 'dig at/for'

b. -táhıra

c. -fúrıra

d. -tcúúngira

e. -wíira

(22) a. -tcúrira

b. -Iímbira

c. -kámıra

d. -kérera

e. -kíbírira

f. -t6wírra

g. -Wúmira 'draw (water) at/for'

'wash (clothes) at/for'

'tie at/for'

'fall at'

'smash completely'

'sing a lot'

'milk (cow) using'

'cut using'

'run towards'

'spit onto'

'dry up concerning' (cf. -bóka 'dig')

(cf. - táha 'draw (water)’)

(cf. -fúla 'wash (clothes)')

(cf. -tcúunga 'tie')

(cf. - wyá 'fall')

(cf. -tcúla 'smash')

(cf. -Ímba 'sing')

(cf. -káma 'milk (cow)')

(cf. -kéra 'cut')

(cf. -kíbıra 'run')

(cf. -tcwá 'spit')

(cf. -wúma 'dry up')

As shown in (23), frozen forms indicated by semantic shift (23a-c) or by lost basic form $(23 \mathrm{~d}-\mathrm{g})$ occur rather frequently.
(23) a. -láhıra
'believe'
(cf. -láha 'promise')
b. -ímira
'start'
(cf. -íma 'stand')
c. -túmira
'be engaged'
(cf. -túma 'send')
d. -wódzera
'wait'
e. -súndira 'kiss'
f. -ákıra
'have in mouth'
g. -húúvira
'fan'

2.2.4. Separative. The Separative is marked with the suffix - $-1-/-o l-$. It is not a productive morpheme, most instances given in (24) having lost any connection to corresponding basic forms.
a. -tcúúngula 'untie'
(cf. -tcúunga 'tie')
b. -kwáátula 'let slip'
(cf. -kwáata 'seize')
c. -ókola
'redeem'
(cf. -óka 'burn')
d. -téćngula
'accompany after visit'
(cf. -téçga 'invite for visit')
e. -pótcola 'pierce'
f. -súlula 'bleed'
g. -sátula 'split lengthwise'
h. -réćngula 'inspect'
i. -púnula 'shave' 
2.2.5. Neuters. Neuters are marked with the suffix $-I k-/-\varepsilon k$ - in general, and the suffix - vk-/-ok-for intransitive forms of the Separative. Neither of these forms is productive, yet there are only a few forms which cannot be traced to a corresponding base.

(25)
a. -jneka
'be visible'
(cf. -óna 'see')
b. -únıka
'be broken'
(cf. - úna 'break')
c. -túrıka
'be cracked'
(cf. -túla 'crack s.th.')
d. -yírıka
'be unconscious'
e. -sáámbuka 'be harmed'
f. -dúmuka 'be torn'
g. -híinduka
'return (intrans.)'
(cf. -sáámbula 'harm, destroy')
(cf. -dúmula 'tear')
(cf. -híindula 'return sth.')

A number of instances of $-I K$ - seem to have a causative (or impositive) meaning. None of those shown in (26) can with certainty be related to corresponding verbs.
(26) a. -lúmıka
'bleed by cupping'
(cf. -lúma 'bite')
b. -láárıka
'invite'
(cf. -láala 'lie down')
c. -árıka
'circumcise'
d. -vércka
'carry on back'
(cf. -ála 'spread')

2.2.6. Other Non-Productive Extensions. The four non-productive extensions with low vowels listed by M\&S92 [p.163-165] for Nyamwezi, viz. -al-, -am-, -an-, and -at-, are all found in Rangi as well. M\&S92 give the following reason for calling the suffix -al-active-positional and the suffix -am-passive-positional:
"Although this extension is not particularly infrequent, its meaning is somewhat obscure. The only case where a corresponding underived verb exists is obviously an old, lexicalized derivation. If 'to sit' is derived from 'to go down', then this suggests that the subject of a verb with the extension -al- has completed the action expressed by the underived verb and is now in the position resulting from it. Some other examples support the hypothesis that this extension describes a position of the body, but the subjects are generally more active than in verbs with the extension -am-." [Maganga \& Schadeberg 1992:163]

Rangi examples of both extensions are given in (27). 


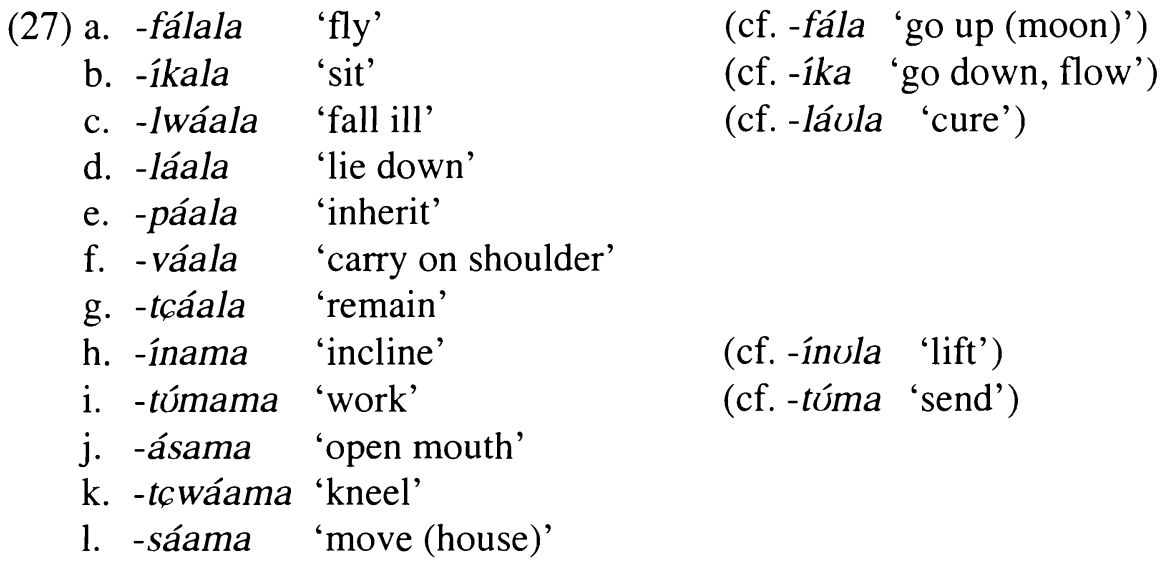

A non-productive form of the Reciprocal is -an- (see footnote 9 for reference to its productive equivalent). As evident in (28), however, establishing corresponding basic forms is difficult at best. Although in (28b-c) both basic forms 'bite' and 'grind' include the idea of 'coming into contact', namely teeth and grinding stones, respectively, such an etymology for the corresponding reciprocals cannot be proven on synchronic grounds.
(28) a. -hákana
'border on'
(cf. muhaká 'border')
b. -lúmana 'meet'
(cf. -lúma 'bite')
c. -cáana 'meet'
(cf. -ca 'grind')
d. -tcáana 'forge'
(cf. -tcúla 'hit, strike')
e. -ífyáana12 'resemble'

The non-productive extension -at- marks the Contactive, as shown in (29).
(29) a. -kwáata 'seize, hold'
b. -lwáata 'tread on'
c. -fyáata 'hold'
d. -fináata 'rub, massage'
e. -ábábáata 'stroke'

2.3. Co-occurences. Unlike any other slot in the Rangi verb structure, the extensional slot can be occupied by more than one marker. The usual order in

\footnotetext{
12 This form probably includes the reflexive/reciprocal prefix -í-, yet without a basic form, that is difficult to determine.
} 
which extensional markers follow each other is given in (30). 13 Table 6 then gives examples of each case of two successive extensional markers.

(30) Separative/Neuter - Applicative - Causative - Passive

Additionally, as shown by the examples in (31), most extensions can co-occur with the Reflexive/Reciprocal -i-, which, of course, is not successive, as it precedes the verb root.

Table 6: Successive extensions

\begin{tabular}{|c|c|c|c|c|c|}
\hline & Separative & Neuter & Applicative & Causative & Passive \\
\hline Separative & $\begin{array}{l}\text {-pángúlula } \\
\text { 'put in disorder' }\end{array}$ & $\begin{array}{l}\text {-húmúluka } \\
\text { 'rest' }\end{array}$ & $\begin{array}{l}\text {-lópgórera } \\
\text { 'lead s.o. to' }\end{array}$ & $\begin{array}{l}\text {-túmburya } \\
\text { 'wake s.o.' }\end{array}$ & $\begin{array}{l}\text {-lóolwa } \\
\text { 'be married' }\end{array}$ \\
\hline $\begin{array}{l}\text { Separative- } \\
\text { Neuter }\end{array}$ & & & $\begin{array}{l}\text {-hííndúkira } \\
\text { 'return for' } \\
\end{array}$ & $\begin{array}{l}\text {-móndokya } \\
\text { 'flatten' }\end{array}$ & $\begin{array}{l}\text {-kálukwa } \\
\text { 'be thirsty' }\end{array}$ \\
\hline Neuter & & & $\begin{array}{l}\text {-íníkıra } \\
\text { 'go down' }\end{array}$ & $\begin{array}{l}\text {-ónckya } \\
\text { 'make visible' }\end{array}$ & $\begin{array}{l}\text {-térckwa } \\
\text { 'be cooked' }\end{array}$ \\
\hline Applicative & & & $\begin{array}{l}\text {-óyérera } \\
\text { 'swim' }\end{array}$ & $\begin{array}{l}\text {-rímirya } \\
\text { 'forget' }\end{array}$ & $\begin{array}{l}\text {-dúmbirwa } \\
\text { 'be praised' }\end{array}$ \\
\hline Causative & & & & & $\begin{array}{l}\text {-váíwa } \\
\text { 'be blown away' }\end{array}$ \\
\hline Passive & & & & & \\
\hline
\end{tabular}

(31) a. -ítcúúngula

b. -ítíka

c. -ífáfira

d. -írúmira

e. -ídzúvira

f. -íyźrya

g. -íláangya 'give birth' (lit. 'untie oneself')

'carry on one's own head'

'defend oneself'

(cf. -fáfa 'be difficult')

'agree with each other'

(cf. -rúma 'assent')

'get used to'

'dance in contest with other men' (cf. -yćra 'measure')

'advise' (lit.: cause to watch oneself)

A few causatives of words containing the non-productive extensions -al-and -an-were found, as shown in (32).

(32)
a. -tcáarya
'leave behind'
(cf. -tcáala 'remain')
b. -lwáarya
'wound s.o.'
(cf. -lwáala 'fall ill')
c. -lúmanya
'make others meet'
(cf. -lúmana 'meet')
d. -ásákánya
'trade, exchange'

13 So far, no counter-examples have been found. 
Examples of more than two successive extensions are given in (33).
(33) a. -kúníkírıra
'cover'
[Neuter + double Applicative]
b. -máríkırya 'finish'
[Neuter + Applicative + Causative]
c. -láhírírya 'order'
[double Applicative + Causative]

The repetition of an extensional marker (observed only for Separative and Applicative) might indicate an intensification of the action. However, a definite semantic difference with the same stem bearing only a single instance of the extension could not be established.
(34)
a. -sámbúlula 'spoil'
(cf. -sáámbula 'harm, destroy')
b. -sáwúlvla 'choose'
(cf. -sáwula 'choose')
c. -téérera 'listen'
(cf. - téera 'hear')
d. -fóśkérera 'spill'
(cf. -fóska 'flow over' and -f́́ókera 'scald')
e. -ryáánírıra 'be equal'

\section{Nominal Derivation}

Nominal derivation, by the very nature of the structure of the noun, makes heavy use of noun class prefixes. However, a few suffixes do occur. As in the section on verbal derivation, productive processes will be discussed before non-productive ones.

3.1. Verbal nouns. As in most Bantu languages, the verb infinitive is formed with $k v-$, the prefix of noun class 15 . This form can function as an argument of a verb as shown in (35a), yet retains some verbal qualities like the inclusion of an object marker, as in (35b).

(35) a. I-sisi rí-sá-náa-va Foolita maá mi-ísoori ya-ka-ánda kv-fúma. 5-moment 5-NEG-PST-be Folita then 6-tear 6-CON-begin 15-occur 'A little while had not yet passed Folita, and (his) tears started (their) occurrence.'

b. Na-sáák-írre ku-í-óna.

1S:PRES-want-APPL:PFV 15-9-see

'I have searched for seeing it.' (refering to a lost arrow)

As shown in (36), these infinitives can stand in subject or object position of a phrase. No other forms of verbal nouns were observed in the Rangi corpus. 
(36) a. Ku-túkıra vaa-ntu kw-á-virha.

15-insult 2-person 15-PRES-be bad

'Insulting people is bad.'

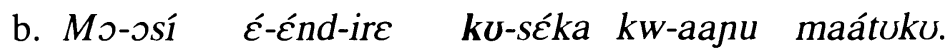
1-old man 3S-love-PFV 15-laugh 15-your(pl) very much 'The old man loved your laughing very much.'

3.2. Agent nouns. Verbs are commonly nominalized by prefixing $m u-$, the prefix of noun class 1 , and suffixing $-i$ an agentive marker. Two indications that this process is still productive are that class 1 agentive nouns bear the same tone as the verbs they are derived from, and that the process is applicable to words like the basic verb of (37d) which has been borrowed from a neighbouring Cushitic language.

(37) a. mutcúundi 'moral teacher' (cf. -tcúunda 'teach morals')

b. mukímndi 'sorcerer' (cf. -kínnda 'bewitch')

c. mutcáani 'blacksmith' (cf. -tçáana 'forge')

d. musákaati 'hunter' (cf. -sákaata'hunt')

e. mulósli 'bridegroom' (cf. -lósla 'marry')

f. mwiívi 'thief' (cf. -íva 'steal')

There are tentative indications that agentivization with the $-i$ suffix was historically applied to other noun classes too, as shown in (38). However, in these cases, tone does not remain stable during the process, i.e., the lexical tone of the noun does not reflect the tone of the original verb.
(38) a. mweع́rí
(cl.3) 'moon'
(cf. -éra 'become light, bright')
b. mikírí
(cl.4) 'soot'
(cf. -kíra 'make dull')
c. kIsuri
(cl.7) 'fart'
(cf. -súla 'fart')
d. kIfwíriríi
(cl.7)
'storm'
(cf. -fwírra 'blow')
e. kılosngi
(cl.7)
'advice'
(cf. -lóonga 'reconcile')
f. upaari
(cl.14) 'inheritance'
(cf. -páala 'inherit')

3.3. Diminutives and augmentatives. The prefix $\mathrm{ka}$ - of class 12 (with plural $\mathrm{fi}$ in 19) is used to form diminutives. While the morpheme is mostly productive, note that (39d) seems to have lexicalized. No derogatory uses of diminutives were found in the corpus. 

(39) a. kanaáwu
'kitten'
(cf. paáwu 'cat')
b. kaána
'infant'
(cf. mwaána 'child')
c. katáampi
'twig'
(cf. itáampi 'branch')
d. kasuvlá
'foreskin'
(cf. isuvlá 'shell, skin')

The prefix $i$ - of class 5 (with plural ma- in 6) is regularly used to form augmentatives. Again, cases of lexicalization like (40d) are observed, whereas no derogatory uses occurred in the corpus.
(40) a. idaafu
'big billy-goat'
(cf. ndaafu 'billy-goat')
b. ikabaakv
'big bull'
(cf. gkabaaku 'bull')
c. isaárI
'coarse sand'
(cf. lusaárı 'sand')
d. itohe
'mud'
(cf. ntohe 'cow dung')

3.4. Qualitative. Noun class 14 with prefix $v$ - contains mainly abstract nouns. One derivational process involves the nominalization of adjectives as shown in (41). As adjectives are presumably a closed class in Rangi, the productivity of the process is limited even though it applies to all members of the adjectival class.

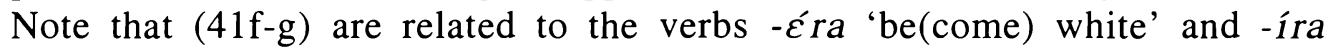
'be(come) dark', respectively, but are here analyzed as nominalizations of adjectives and not of verbs.
(41) a. vkứrlu
'bigness, size'
(cf. -kứulu 'big')
b. vdúúdi
'smallness'
(cf. -dúúdi 'small')
c. vlíhi
'length'
(cf. -líihI 'long')
d. vkúfí
'shortness'
(cf. -kúfí 'short')
e. vruts
'weight'
(cf. -ruto 'heavy')
f. weEru
'whiteness, light'
(cf. - $\varepsilon r v$ 'white, light')
g. wiiru
'blackness, darkness'
(cf. -iru 'black, dark')

It is also possible, however, to replace the prefixes of nouns from other classes with class 14 prefix $v$-, thus forming an abstract noun, as shown in (42). This does not seem to be a productive process, however.
(42) a. woosi
'old age'
(cf. moosi 'elder')
b. vkabaaku 'strength'
(cf. pkabaakv 'bull')
c. usáví
'witchcraft'
(cf. musáví 'witch')
d. uUntu
'being, personhood'
(cf. muvntu 'person') 
3.5. Peoples, languages, and countries. There is a regular relationship between people groups in classes $1 / 2$, and their languages and countries in classes 7 and 14 , respectively, as shown in (43). Note, however, the exception of the Rangi country in $(43 \mathrm{c}){ }^{14}$
a. mumbuUwe, vambuUwe
kImbuUwe, umbuUwe
'Mbugwe man, people'
b. mufyóomi, vafyóomi
kıfyóomI, ufyóomI
'Mbugwe language, country'
'Gorowa man, people'
'Gorowa language, country'
c. mulaangi, valaangi
kılaangi, iraangi
'Rangi man, people'
'Rangi language, country'

3.6. Non-productive processes. The nominal derivational processes which are described in the following two sections are no longer productive in Rangi.

3.6.1. Verb-to-noun derivation. As in many East African Bantu languages, the most common non-productive verb-to-noun derivational process makes use of the suffix - $\supset$ which may have carried a meaning of 'instrumental'. It is found throughout all noun classes except classes $1 / 2$. Note that some words include the applicative suffix -Ir-, especially body parts in classes $5 / 6$ (44i and 1, the latter plus causative $-y$-) and instruments (44h, k, o, r, v), whereas other words denoting instruments are formed directly from the underlying verb $(44 a, b, q)$. A possible explanation could be that the former words necessarily include the notion of movement which the latter lack.

(44) classes $3 / 4$
a. mukwáato
'tongs'
(cf. - kwáata 'seize')
b. mutírko 'ladle'
(cf. -tírka 'put up on another')
c. mukóodzo
'urine'
(cf. -kósdza 'urinate')
d. murims
'work'
(cf. -ríma 'farm')
e. mufuls 'river'
(cf. -fúla 'move')
f. mugírits 'slope'
(cf. -gírita 'descend')

\section{class 4}

g. mirwyáals 'clothes' (cf. -rwyáala 'wear')

14 An explanation of this irregularity could be found in possible influence from Bantu $\mathrm{F}$ languages further to the West in which the respective countries' self-referents are Irimi, Iramba and Isanzu. 


\section{classes $\mathbf{5 / 6}$}
h. ifyaahıro
'broom'
(cf. -fyááhıra 'sweep')
i. itcwáámıro 'knee'
(cf. -tcwáama 'kneel')
j. ikáángulo 'scraping tool'
(cf. -káángula 'scrape clean')
k. ikúlúsiro 'whetstone'
(cf. -kúlusa 'scrape')
1. ilwaatirys
'foot'
(cf. -lwáata 'tread on')
m. ipsótco
'broken eye'
(cf. -pótcola 'pierce')
n. irrho
'payment'
(cf. -ríha 'pay')
o. iciíro
'grinding stone'
(cf. - ca 'grind')
class 6
p. malólóso 'quarrel' (cf. -lólósa 'quarrel')

\section{classes $7 / 8$}

q. kıkálaang
'frying pan'
(cf. -kálaanga 'roast, fry')
'mourning wail'
(cf. -láanga 'watch')
(cf. -ríra 'cry')

r. kıláángıro 'mirror'

s. kIrIro

\section{classes $9 / 10$}
t. firrro
'other side'
(cf. -firrra 'jump')
u. mpero
'end'
(cf. -hérya 'finish')
v. நkulungírs
'pottery tool'
(cf. -lúngira 'make even')

classes 11/10

w. luseko

'laughter'

(cf. -sćka 'laugh')

x. lusíms

'tale, story'

(cf. -síma 'tell a story')

y. luhíndo 'barrier'

(cf. -hímnda 'put across')

\section{class 14}

z. ufúms

The remainder of verb-to-noun derivation hardly shows any pattern. Identifiable suffixes might be $-I$ with class 1 , as in (45a-c), -wa as in $(45 \mathrm{~d}-\mathrm{h})$, which originates from passive verb forms, and -ya as in $(45 \mathrm{i}-\mathrm{j})$ from causative verb forms.
'sick person (cl.1)'
'parent (cl.1)'
b. muvý́rI
'rich person (cl.1)'
c. musúngaati
d. murerwá
'dependent (cl.1)'
e. mutúmwa
'slave (cl.1)'
(cf. -lwáala 'fall ill')
f. kryuolwa 'evening meal (cl.7)'
(cf. - vyáala 'beget, give birth')
(cf. sungaata'become rich')
(cf. -réra 'raise (child)')
(cf. -túma 'send')
(cf. -yúula 'open') 

g. ndííwá 'food (cl.9)'
(cf. -ryá 'eat')
h. luumbwa 'earthenware (cl.11)'
(cf. -úmba 'make pottery')
i. raávya 'caterpillar species (cl.5)'
(cf. -áva 'itch')
j. kIlwírya 'darkness (cl.7)'
(cf. -íra 'become dark')
k. itambaala 'snail (cl.5)'
(cf. -támbaala 'spread, crawl')
1. Inkwya
'death (cl.9)'
(cf. -kwya 'die')
m. bwitú
'game (cl.9)'
(cf. -bwíta 'play')
n. nkalaru
'anger (cl.9)'
(cf. -kálala 'become angry')

3.6.2. Noun-to-noun derivation. There are three kinds of non-regular relationships between items of noun classes, one between plants and their fruits, another relating human beings with nouns of other classes, and a third one involving pairs of nouns without a regular pattern of relation. The plant-fruit relationship exhibits three categories, the first with the plant in class 3 and its fruit in class 5 , as shown in (46a), the second with the plant in class 3 and its fruit in class 9, as in (46b), and the third with the plant in class 11 and its fruit in class 5, as in (46c).

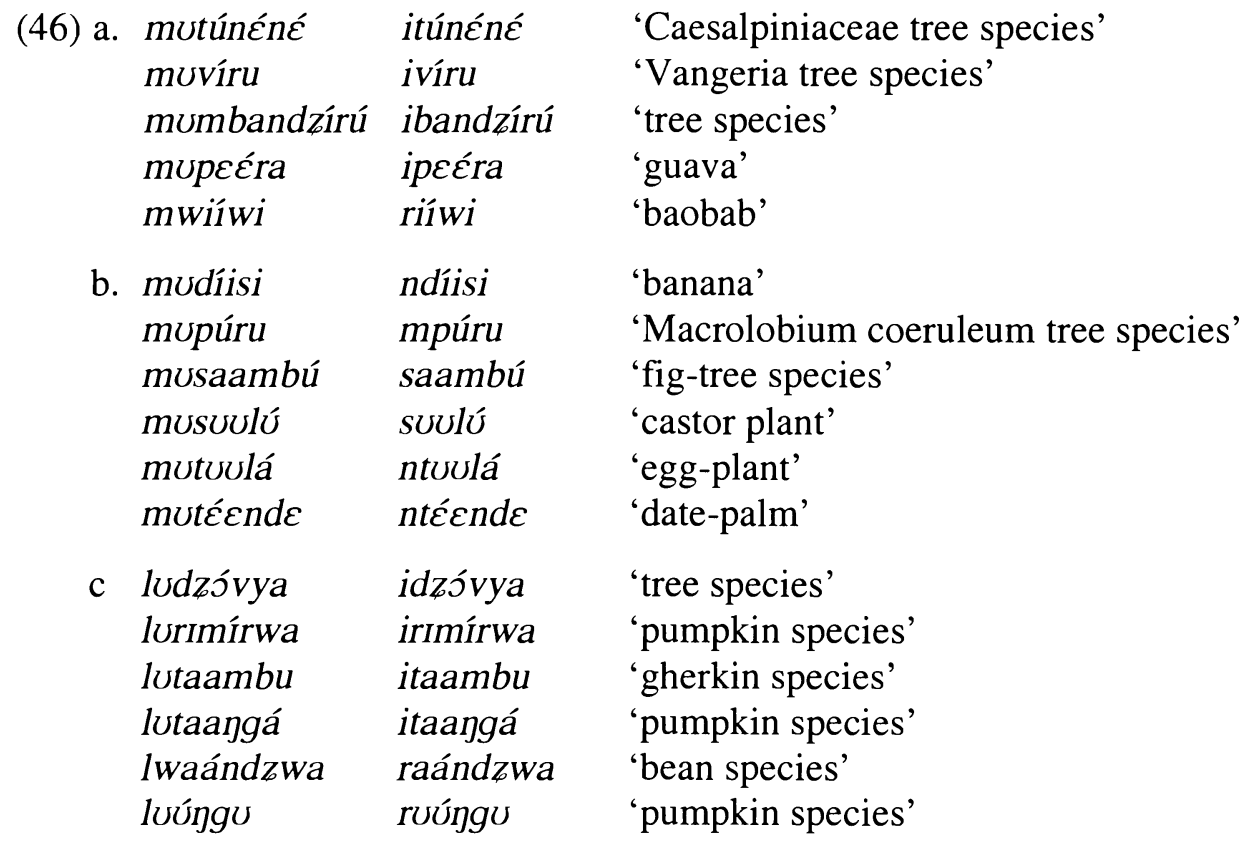

Some nouns of class 1 can be linked to members of other noun classes. However, it is not possible to establish with certainty which direction a derivational process took, if these are indeed cases of derivation. 


$\begin{array}{cll}\text { (47) a. mukaáya } & \text { 'neighbour' } & \text { (cf. cl.9 kaáya 'homestead')15 } \\ \text { b. mumaka } & \text { 'guy' } & \text { (cf. cl.9 maka 'animal') } \\ \text { c. mundứ } & \text { 'relative' } & \text { (cf. cl.9 ndứ 'relative in general') } \\ \text { d. movntu } & \text { 'person' } & \text { (cf. cl.7 kIIntu 'thing') }\end{array}$

For the noun pairs shown in (48), no rule of relationship can be established. The items in (48d-f) might be due to lexicalized augmentatives, though.

\begin{tabular}{|c|c|c|c|c|c|}
\hline a. $\operatorname{cl} 3$ moong & 'back' & versus & $\mathrm{cl} .7$ & kıоoฤgo & 'mountain ridge' \\
\hline $\mathrm{cl} .7 \mathrm{kId} d \mathrm{du}$ & 'chin' & versus & cl.9 & $n d \varepsilon d u$ & 'beard' \\
\hline cl.9 ndzukI & 'bee' & versus & cl.14 & UvkI & 'honey' \\
\hline cl.5 itímá & 'liver' & versus & $\mathrm{cl} .3$ & mutímá & 'heart' \\
\hline cl.5 ivaru & 'body side' & versus & cl.11 & luvaru & 'rib’ \\
\hline f. cl.5 itóómbó & 'breast' & versus & cl.11 & lutóómbó & 'udder' \\
\hline
\end{tabular}

\section{Conclusion}

In addition to filling a descriptive gap in Bantu linguistics, it is hoped that this paper also has given indications of the place of Rangi within the bigger picture. First, it was shown that, contrary to reports in previous publications, Rangi nouns are tonally fully distinctive. Second, Rangi was classified as exhibiting canonical, i.e. asymmetric Vowel Height Harmony as defined by Hyman [1999], and as having a seven [i I $\varepsilon$ a $\supset$ $v$ u] vowel system with regular [+ATR] dominance as predicted by Casali [1998]. Third, Rangi's derivational processes have been described in detail. Most of the derivational processes reported by M\&S92 for Nyamwezi could be found in Rangi. The most common processes include the wide range of verbal extensions from the productive Passive, Causative and Applicative to a number of cognate non-productive suffixes, as well as agentive $-i$ suffix, diminutives and augmentatives formed with prefixes of noun classes 12 and 5 respectively, and widespread vestiges of an instrumental -o suffix. Of course, all of these phenomena are indicative of many Eastern Bantu languages and, indeed, can be traced to Proto-Bantu [Guthrie 1967-71IV:215-218]. The description as such may serve as a first step in solving the puzzle of Rangi's genetic affiliation, viz. that it is "not obviously unambiguously related to any other East African group" [Nurse 1999:11]. Providing more insights by way of a detailed comparison with other related, though not immediately neighbouring

15 Kaáya is probably the original word as cognates of it are found in many Bantu languages, but not of the form mukaáya. 
languages to the West (Bantu F), to the North (Bantu E) and to the South-East (Bantu G), will have to be left to further studies.

\section{REFERENCES}

Akhavan, Firouzeh. 1990. "Untersuchungen zur Grammatik des Irangi anhand des Materials aus dem Nachlass Dr. Paul Berger." MA thesis, University of Hamburg.

Casali, Rod. 1998. "Predicting ATR Activity." Papers from the Regional Meeting of the Chicago Linguistic Society 34,1:55-68.

Dempwolff, Otto. 1916. "Beiträge zur Kenntnis der Sprachen in DeutschOstafrika - 8. Irangi." Zeitschrift für Kolonialsprachen 6:102-23.

Dunham, Margaret. 2001. "Description ethno-linguistique des Valangi de Tanzanie." Doctoral thesis, University of Paris III.

Grimes, Barbara (ed.). 2000. "Ethnologue, Languages of the World." Fourteenth edition, Dallas: Summer Institute of Linguistics.

Guthrie, Malcolm. 1967-71. Comparative Bantu, Volumes I-IV. Farnborough: Gregg.

Hyman, Larry. 1999. "The Historical Interpretation of Vowel Harmony in Bantu." In Jean-Marie Hombert \& Larry Hyman (eds.), Bantu Historical Linguistics. Stanford: CSLI. Pp. 235-295.

Maganga, Clement and Thilo Schadeberg. 1992. Kinyamwezi-Grammar, Texts, Vocabulary. Köln: Rüdiger Köppe.

Nurse, Derek. 1999. "Towards a Historical Classification of East African Bantu Languages." In Jean-Marie Hombert \& Larry Hyman (eds.), Bantu Historical Linguistics. Stanford: CSLI. Pp. 1-41. 
Schadeberg, Thilo. To appear. "Derivation." In Derek Nurse and Gérard Philippson (eds.), The Bantu Languages. London: Curzon Press.

Seidel, Alfred. 1898. "Grammatik der Sprache von Irangi." In Waldemar Werther (ed.), Die mittleren Hochländer des nördlichen Deutsch-Ost-Afrika. Berlin. Pp. 387-434.

S.I.L.

P. O. Box 21

Kondoa, Tanzania

Oliver_Stegen@sil.org
[Received July 2002;

accepted January 2003] 
